\title{
Physiological energetics of Littorina littorea under combined pollutant stress in field and mesocosm studies
}

\author{
T. Bakke \\ Norwegian Institute for Water Research, PO Box 333, N-0313 Blindern, Oslo 3, Norway
}

\begin{abstract}
Rates of energy turnover processes (ingestion, food absorption efficiency, ammonia excretion, respiration) and their integration into an energy budget (scope for growth) was estimated in GEEP Workshop samples of periwinkles Littorina littorea taken from 4 populations in Langesundfjord, Norway, and from 4 populations which had been kept in mesocosms at different levels of exposure to oil and copper for $4 \mathrm{mo}$. Periwinkles from the most contaminated field site had an elevated scope for growth. The physiological measurements failed to discriminate among mesocosm treatments. Use of physiological energetics of $L$. littorea in biological effects monitoring is, at present, premature; it demands both method development and better understanding of the factors regulating the energy conversion processes.
\end{abstract}

\section{INTRODUCTION}

Periwinkles Littorina littorea are responsive to oil contamination (Widdows et al. 1981, Bakke 1986) Furthermore, $L$. littorea is a key species in boreal rocky shore communities, and represents a feeding type (i.e. substrate grazer) different from mussels Mytilus edulis (filter feeder) which are commonly used to monitor marine contamination. These 2 species therefore reflect different routes of entry of contaminants to the biota and might be expected to yield different information regarding the biological impact of pollution.

The purpose of this investigation was to obtain estimates of the rates of energy conversion (uptake and utilization of food) in 8 populations of Littorina littorea, and to evaluate how the energy condition of samples from these populations reflected pollution gradients. Four samples were collected in Langesundfjord, Norway, at sites representing an assumed contamination gradient. These sites were designated 1,2,3 and 4, from the outer to the inner part of the fjord (Follum \& Moe 1988). The other 4 samples were taken from a mesocosm experiment at the Marine Research Station, Solbergstrand, in which 3 basins were dosed for 4 mo with different concentrations of a diesel oil and copper mixture ( $\mathrm{L}$ : low, $\mathrm{M}$ : medium, $\mathrm{H}$ : high dose), with a 4 th basin (C) serving as a control (Bakke et al, 1988).

\section{MATERIAL AND METHODS}

Physiological measurements were in general based on samples of 10 individuals of Littorina littorea of uniform shell size, the main constraint on sample size being time to perform the measurements. For estimating food absorption efficiency groups of 40 to 50 individuals were used. All measurements were performed at Solbergstrand over a period of $2 \mathrm{wk}$; measurements for a single sample were all completed in 3 to $4 \mathrm{~d}$. The investigation was carried out 'blindly', i.e. on coded samples. Between measurements, periwinkles were kept in running sea water with ample supply of food (green alga Ulva lactuca). Field samples were kept in water pumped from $1 \mathrm{~m}$ depth outside Solbergstrand $\left(17^{\circ} \mathrm{C}\right)$; mesocosm samples were kept in the appropriate mesocosm basin $\left(10^{\circ} \mathrm{C}\right)$. After all the physiology measurements had been performed, the periwinkles were killed by rapid immersion in boiling sea water, and shell height, tissue wet weight, dry weight and ash content determined for each individual. Temperatures applied for drying and ashing were $100^{\circ} \mathrm{C}(24 \mathrm{~h})$ and $450^{\circ} \mathrm{C}(2 \mathrm{~h})$, respectively.

Feeding rate. Food uptake rates were estimated by incubating individual periwinkles in flow through cages (volume $72 \mathrm{ml}$ ) with preweighed pieces of Ulva lactuca (about $50 \mathrm{mg}$ wet wt). This alga is ranked high 
as preferred food for Littorina littorea (Lubchenko 1978). For each periwinkle population, 5 cages with $U$. lactuca alone were prepared as blanks. Cages were checked after $24 \mathrm{~h}$, and individuals which had not consumed a significant portion of the food were allowed to feed for another $24 \mathrm{~h}$. After feeding, food remains and blank pieces were reweighed. The blank pieces of $U$. lactuca were subsequently used to obtain the relation between wet weight, dry weight and ash content of the food. Weighing was done after rapid blotting of excess water, which when standardised gave a coefficient of variation of $1.8 \%$ of the mean weight at repeated weighings.

Food consumption was calculated as joules ind. ${ }^{-1}$ $\mathrm{d}^{-1}$, using the expression:

$$
24 J_{1}\left[A_{0}(1+k)-A_{t}\right] / t
$$

where $A_{0}$ and $A_{t}=$ wet weight of food at time 0 and $t_{i}$ $k=$ mean fraction weight change in blanks (usually about +0.03$) ; t=$ feeding time $(\mathrm{h}) ; J_{1}=$ conversion factor from wet weight to energy units (joules) for Ulva lactuca. A value of $19.88 \mathrm{~J} \mathrm{mg}^{-1}$ AFD of $U$. lactuca was derived from Paine \& Vadas (1969). Although frequently used with Littorina littorea, this procedure will only give a relative estimate of feeding rate. The accuracy of the estimate depends on the time it takes the periwinkle to find the food (ratio between food area and total chamber area was 1:20), the stimuli keeping the periwinkle on the food, and how well $U$. lactuca represents the natural diet of a population. Nonetheless, a relative estimate should be applicable for comparison between samples in a monitoring context.

Food absorption efficiency. The fraction of food adsorbed was estimated from the short-cut expression of Conover (1966) based on the organic fraction of food and faeces (cf. Grahame 1973, for an evaluation of this procedure on Littorina littorea). Quantitative sampling of faeces is not required, but was carried out nevertheless, in order to be able to relate faecal production rate to food consumption. Faecal production had to be estimated from groups of 40 to 50 ind. to obtain enough faecal material for gravimetric determination. Single group estimates give an indication of population differences but these cannot, of course, be tested. Absorption efficiency estimation on single individuals is feasible, but would require organic content determination by use of microcalorimetry, microbalance or elemental carbon analysis.

The groups were fed Ulva lactuca for at least $3 \mathrm{~d}$ prior to the experiment. Each group was incubated for about $15 \mathrm{~h}$ in a $1 \mathrm{I}$ chamber with solid bottom and gentle water exchance, whereafter all faecal material was filtered onto incinerated and tared GF/C filters. Any non-faecal material was removed under micro- scope, and filters were dried and incinerated to obtain dry weight and organic content of the faeces.

Oxygen consumption. Individual aquatic oxygen consumption of Littorina littorea was estimated in closed respiration chambers $(60 \mathrm{ml})$ supplied with a magnetic stirrer and a YSI model 5331 oxygen probe connected to a chart recorder. The chamber was immersed in a water bath of appropriate temperature. Individuals were kept in the chamber long enough to obtain a reliable linear recorder track, usually 30 to 40 min. Oxygen consumption was calculated as $\mu \mathrm{l} \mathrm{O}_{2}$ ind. ${ }^{-1} \mathrm{~h}^{-1}$ using the expression:

$$
\left[60 v\left(V_{0}-V_{t}\right) / t\right]-b
$$

where $V_{0}-V_{t}=$ change in oxygen concentration $\left(\mathrm{ml} \mathrm{O}_{2}\right.$ $1^{-1}$ ) in the chamber from time 0 to $t_{i} v=$ chamber net water volume; $b=$ oxygen consumption of empty chambers. This value was converted to $\mathrm{J}_{\text {ind. }}{ }^{-1} \mathrm{~d}^{-1}$ through multiplication by a factor 0.4822 based on an oxycalorific coefficient of $4.8 \mathrm{cal}\left(\mathrm{ml} \mathrm{O}_{2}\right)^{-1}$ (Crisp 1971).

Ammonia nitrogen excretion. Ammonia excretion rate was estimated by incubating single periwinkles for $2 \mathrm{~h}$ in glass beakers with $70 \mathrm{ml} \mathrm{GF} / \mathrm{C}$ filtered sea water. Field individuals were incubated in water from $1 \mathrm{~m}$ depth, others in control mesocosm water. For each population 2 blank beakers with sea water were included. After incubation, samples were preserved with $0.7 \mathrm{ml} 8 \mathrm{~N}$ sulphuric acid and analysed for $\mathrm{NH}_{4}^{+}-\mathrm{N}$ after the method of Solorzano (APHA 1985). Excretion rates were calculated as $\mathrm{J}$ ind.$^{-1} \mathrm{~d}^{-1}$ from the following expression:

$$
0.84 J_{2}\left(N_{2}-N_{0}\right)
$$

where $\mathrm{N}_{2}=$ concentration of ammonia nitrogen (ug $\mathrm{N}$ $1^{-1}$ ) in the periwinkle beaker at time $2 \mathrm{~h} ; N_{0}=$ corresponding mean blank concentration at time $2 \mathrm{~h}_{\mathrm{i}} J_{2}=$ conversion factor from ammonia to joules based on a value of $24.86 \mathrm{~J}\left(\mathrm{mg} \mathrm{N}^{-1}\right.$ (Elliott \& Davison 1975).

Scope for growth. The energy available for growth and gamete production, called the 'scope for growth' or SFG (Warren \& Davies 1967) was calculated for each periwinkle as the difference between the rates of energy gain (food absorbed) and energy loss (respiration and excretion) all expressed in $\mathrm{J} \mathrm{d}^{-1}$.

Statistics. Population differences in mean food consumption, respiration, excretion, SFG, and tissue dry weight:shell length ratio were tested by 1-way ANOVA on untransformed and log-transformed data. Differences between pairs of populations were tested with the 2-group $t$-test, using the pooled standard deviation estimates from the ANOVA. All differences described below were significant at the $5 \%$ level or better. Tests were performed with the MINITAB statistical package (Pennsylvania State Univ.) implemented on the NIVA NORD $100 \mathrm{CX}$ computer. 


\section{RESULTS}

\section{Contamination gradient}

Analyses of 2- and 3-ring aromatic hydrocarbons in tissues of Littorina littorea (Appendix 1, Fig. 1) indicate that periwinkles from Sites 2,3 and 4 were more contaminated than those from Site 1. Data are not available for trace metals in L. littorea, but the analyses of Mytilus edulis (Abdullah \& Steffenak 1988) suggested slighly less contamination at Site 1 , with no clear gradient among the other sites. Physiological measurements on $L$. littorea are therefore evaluated against an assumed contamination gradient $4=3=2$ $>1$. Mesocosm population responses are evaluated against the known gradient of pollutant exposure: $\mathrm{H}>$ $\mathrm{M}>\mathrm{L}>\mathrm{C}$ (Bakke et al. 1988).

\section{Food uptake and absorption}

For the field sites, food-uptake measurements demonstrated significant population differences. Site 4 periwinkles had higher feeding rates than the others (Table 1). Site 3 showed the lowest feeding rate, although not significantly below Sites 1 and 2 ; Sites 1 and 2 were not different. Samples from Sites 2 and 3 had 1 to 3 non-feeding individuals. Exclusion of these shifted the ranking of Sites 1 and 2, but did not change the general trend. The results are therefore assumed to reflect real population grazing rates. Correspondence between these results and the contamination gradient was therefore weak.

In the mesocosms, food uptake did not differ significantly between basins (Table 1). Exclusion of nonfeeders did not improve the resolution, but a slight

Table 1 Littorina littorea. Estimates of food ingestion rate $\left(\mathrm{J} \mathrm{d}^{-1}\right.$, mean $\left.\pm \mathrm{SD}, n=10\right)$, ingestion rate of active individuals only (numbers in brackets) and absorption efficiency (AE)

\begin{tabular}{|c|c|c|c|}
\hline Source & $\begin{array}{l}\text { Food ingestion } \\
\text { (all) }\end{array}$ & $\begin{array}{l}\text { Food ingestion } \\
\quad \text { (active) }\end{array}$ & $\begin{array}{l}\mathrm{AE} \\
\%\end{array}$ \\
\hline \multicolumn{4}{|l|}{ Site } \\
\hline 1 & $61.7 \pm 31.5$ & $61.7 \pm 31.5(10)$ & 78.2 \\
\hline 2 & $53.0 \pm 44.4$ & $74.9 \pm 32.8$ & 86.8 \\
\hline 3 & $30.4 \pm 24.9$ & $33.4 \pm 24.4$ & 83.3 \\
\hline 4 & $99.4 \pm 31.6^{\circ}$ & $99.4 \pm 31.6(10)^{\circ}$ & 87.3 \\
\hline \multicolumn{4}{|l|}{ Basin } \\
\hline C & $56.7 \pm 37.2$ & $70.3 \pm 26.9$ & 89.5 \\
\hline $\mathrm{L}$ & $80.9 \pm 35.4$ & $80.9 \pm 35.4 \quad(10)$ & 90.3 \\
\hline M & $53.5 \pm 25.1$ & $53.5 \pm 25.3(10)$ & 82.2 \\
\hline $\mathrm{H}$ & $51.7 \pm 50.6$ & $57.4 \pm 50.1$ & 85.3 \\
\hline \multicolumn{4}{|c|}{$\begin{array}{l}\text { For field sites, significant differences from the reference } \\
\text { site (1) indicated by } p<0.05\end{array}$} \\
\hline
\end{tabular}

trend for $\mathrm{C}$ and $\mathrm{L}$ periwinkles to show higher mean feeding rates than $\mathrm{M}$ and $\mathrm{H}$ individuals was indicated (Table 1).

Absorption efficiency was generally high (78 to $90 \%$, Table 1). Differences among samples showed no consistent trend with contamination, neither for field nor mesocosm data.

\section{Respiration and excretion}

For the field sites, respiration measurements demonstrated significant population differences (Table 2). Values for Sites 1 and 2 were significantly higher than those for Site 4 ; Site 1 was not different from Site 2, but had higher values than Site 3 . In all samples, except Site 1, there were individuals with clearly reduced crawling activity during measurement, reflecting the contamination gradient. These periwinkles showed significantly reduced mean oxygen consumption. Omitting the obviously less active individuals shifted the ranking between Sites 1 and 2 and removed the difference between Sites 1 and 3, leaving values for Site 4 below 1 and 2 (Table 2).

In the mesocosms, oxygen consumption was lower than in the field populations (Table 2), and significant differences between basins were detected. Periwinkles from $\mathrm{C}$ had higher mean oxygen consumptions than those from other basins. H, M and L measurements were not different and indicated no dose response trend. Omitting the passive individuals still resulted in highest respiration in $\mathrm{C}$, with no differences amongst the other basins.

Field populations 2, 3 and 4 had very low ammonia excretion rates (Table 2). Population 1 had a signifi-

Table 2. Littorina littorea. Estimates of rates of oxygen consumption (all individuals and active ind only, numbers in brackets) and ammonia excretion ( $\mathrm{J} \mathrm{d}^{-1}$, mean $\pm \mathrm{SD}, n=10$ )

\begin{tabular}{|c|c|c|c|}
\hline Source & $\begin{array}{c}\text { Oxygen } \\
\text { consumption } \\
\text { (all) }\end{array}$ & $\begin{array}{c}\text { Oxygen } \\
\text { consumption } \\
\text { (active only) }\end{array}$ & $\begin{array}{l}\text { Ammonia } \\
\text { excretion } \\
\text { (all) }\end{array}$ \\
\hline \multicolumn{4}{|l|}{ Site } \\
\hline 1 & $63.9 \pm 9.5$ & $63.9 \pm 9.5(10)$ & $3.1 \pm 0.9$ \\
\hline 2 & $62.4 \pm 14.8$ & $67.7 \pm 14.1$ & $0.3 \pm 0.9 \cdots$ \\
\hline 3 & $53.1 \pm 11.2^{\circ}$ & $58.9 \pm 3.7$ & $0.1 \pm 0.1 \cdots$ \\
\hline 4 & $48.8 \pm 6.6^{\cdots}$ & $50.8 \pm 1.9 \quad(6)^{\circ}$ & $0.3 \pm 1.0^{\cdots}$ \\
\hline \multicolumn{4}{|l|}{ Basin } \\
\hline C & $41.3 \pm 8.3$ & $41.3 \pm 8.3(10)$ & $1.9 \pm 0.9$ \\
\hline $\mathrm{L}$ & $32.9 \pm 4.9^{\circ}$ & $32.8 \pm 5.2(9)^{\circ}$ & $1.9 \pm 0.9$ \\
\hline M & $33.6 \pm 8.0^{\circ}$ & $34.4 \pm 8.0$ & $2.6 \pm 1.1$ \\
\hline $\mathrm{H}$ & $34.1 \pm 6.3^{\circ}$ & $34.1 \pm 6.3(10)^{\circ}$ & $1.9 \pm 0.9$ \\
\hline
\end{tabular}


cantly higher rate than these. Ammonia excretion in mesocosm periwinkles was slightly less than in Field population 1, but no significant differences between basins were found.

The $\mathrm{O}: \mathrm{N}$ ratio from Field site 1 was significantly lower than that for the other sites. Mesocosm samples had about the same $\mathrm{O}: \mathrm{N}$ ratios as Field site 1 , with no significant differences among mesocosm basins.

\section{Scope for growth and body size}

In the field, there was no clear relationship between SFG and the contamination gradient (Table 3). Periwinkles from Site 4 had higher SFG than those from the other populations, both due to higher feeding rate and lower respiration, and they were the only field population with a positive mean SFG value. Populations 1, 2 and 3 did not differ significantly. For the mesocosm experiment, mean SFG was higher in $\mathrm{L}$ periwinkles than in those from other basins but this difference was not significant (Table 3). SFG did not reflect pollution exposure.

Table 3. Littorina Littorea. Estimates of scope for growth and measurement of tissue dry weight and dry weight:shell length ratio $\left(\mathrm{mg} \mathrm{mm}^{-1}\right)_{\text {i }}$ mean $\pm \mathrm{SD}, n=10$

\begin{tabular}{|cccc|}
\hline Source & $\begin{array}{c}\text { Scope for } \\
\text { growth }\left(\mathrm{J} \mathrm{d}^{-1}\right)\end{array}$ & $\begin{array}{c}\text { Tissue dry } \\
\text { weight }(\mathrm{mg})\end{array}$ & $\begin{array}{c}\text { Weight: length } \\
\text { ratio }\end{array}$ \\
\hline Site & & & \\
1 & $-0.79 \pm 1.25$ & $203.9 \pm 53.6$ & $9.8 \pm 2.5$ \\
2 & $-0.70 \pm 1.91$ & $219.0 \pm 25.2$ & $9.9 \pm 1.0$ \\
3 & $-1.16 \pm 0.97$ & $203.1 \pm 24.3$ & $9.5 \pm 1.1$ \\
4 & $1.63 \pm 1.19 \cdots$ & $183.1 \pm 30.8$ & $8.8 \pm 1.4$ \\
Basin & & & \\
C & $0.31 \pm 1.34$ & $192.6 \pm 39.3$ & $8.9 \pm 1.8$ \\
L & $1.60 \pm 1.42$ & $177.1 \pm 27.0$ & $8.7 \pm 1.3$ \\
M & $0.33 \pm 1.00$ & $172.8 \pm 18.9$ & $8.5 \pm 0.8$ \\
H & $0.34 \pm 1.67$ & $147.1 \pm 31.3 \cdots$ & $7.1 \pm 1.4 \cdots$ \\
Significant differences from Site 1 (for field sites) and Basin \\
C (for mesocosm basins) indicated by $p<0.05, \cdots p<0.01$ \\
\hline
\end{tabular}

For body size measurements, the mean dry-weight to shell-length ratio did not differ between field sites but, in the mesocosm experiment, both dry weight and weight-to-length ratio decreased significantly for $\mathrm{H}$ periwinkles (Table 3).

\section{DISCUSSION}

Physiological measurements on Littorina littorea from Langesundfjord separated most clearly Population 4 from the others as having the best energetic status, expressed as SFG. This was due to highest food uptake rate as well as least energy expenditure in respiration. Food absorption in Site 4 periwinkles was at least as efficient as in the other field populations. The reason for this is uncertain, since periwinkles from Site 4 showed levels of contamination by PAH similar to Sites 2 and 3, and higher than Site 1 (Appendix 1). The cytochemical responses in lysosomes (Moore 1988) indicated that Site 4 periwinkles were stressed, but no information on potential stressors can be derived from that. On the other hand, the values for cytochrome P-450 and P-450 reductase activity in Population 4 (Livingstone 1988) were similar to those in Population 1 , and higher than in 2 and 3 , and hence did not indicate responses to organic xenobiotic contamination. These indices responded clearly to oil exposure in the mesocosms.

In contrast to the other sites, Field site 4 was characterised by a dense cover of green algae, mainly Enteromorpha sp. and Cladophora sp. (Follum \& Moe 1988), on which a scattered population of periwinkles was grazing. The ample supply of food, which could be ingested presumably without much energy spent in crawling and radula activity, may have compensated for any energetic disadvantage due to chemical contamination. Reduced activity may explain why the Site 4 periwinkles had lower respiration rates than those in the other field sites, but it does not explain the higher feeding rate when incubated with Ulva lactuca as food. If on the other hand Site 4 periwinkles were at an energetic disadvantage, which might be inferred from their cytochemical responses, the intensive feeding during the measurement may have been a behavioural over-reaction when offered clean water and food.

The physiological measurements failed to discriminate among the treatments in the mesocosm experiment, though the results indicated possibly elevated feeding intensities in $\mathrm{C}$ and $\mathrm{L}$. No clear evidence of dose-related response in respiration rate was demonstrated, except that $H, M$ and $L$ periwinkles had suppressed oxygen consumptions compared to $\mathrm{C}$ and to earlier measurements on control winkles (Bakke unpubl.)

In summary, the physiology of Littorina littorea did not reflect the contamination gradient in field sites or mesocosm basins in a systematic and predictive way. The 2 major components of the SFG calculation feeding and respiration - are both dependent on the periwinkle behaviour, and factors regulating activity, erratic or periodic, are largely unknown. Activity differences are also difficult to detect and at present impossible to quantify; they will therefore create substantial uncertainty in the estimates.

The variability in food ingestion rates shown by Littorina littorea reflects fluctuation in grazing activity. 
Field observations clearly demonstrate that periwinkles have long inactive periods, and feeding experiments over several days (Bakke unpubl.) have shown that non-feeders suddenly may start grazing, or that grazing may stop for a while. Reliable estimates of average individual ingestion rate therefore have to be based on incubation with food for an extended period of time, preferably $1 \mathrm{wk}$, to cover both active and quiescent periods. In the context of the GEEP Workshop this was prohibitive, and the necessity of running feeding experiments over such a long time may also be a logistic argument against use in practical monitoring.

There is at present little systematic knowledge on how periwinkles behave in response to fluctuations in food availability and quality, illustrated by the uncertainty as to whether the high feeding rate for Site 4 periwinkles reflected normal rates or hyperactivity when offered clean Ulva lactuca as food. Standardisation by pre-conditioning the periwinkles to a certain type of food can be of value if done in situ, and with food taken from the site in question. One explanation proposed for the lack of response in the mesocosm populations is that they were fed clean $U$. lactuca during the 4 mo exposure (Bakke et al. 1988).

The influence of locomotory activity on oxygen consumption in Littorina littorea (e.g. Newell \& Pye 1971) adds to the variability in population mean estimates. Leaving out obviously passive individuals may reduce the scatter of the data, but subtle differences in activity enough to change respiration are difficult to detect; this makes it uncertain as to whether differences in respiration are due to behavioural response or effects on metabolism. The knowledge on whether pollutants suppress or enhance respiration in periwinkles is sparse. Hargrave \& Newcombe (1973) showed that treatment with oil enhanced respiration in $L$. littorea, whereas treatment with a dispersant caused a reduction. Comparable resuits on metal contamination in periwinkles have not been presented. In mussels it has been demonstrated that different metals may affect oxygen consumption differently, e.g. an increase with silver (Thurberg et al. 1974) and a decrease with copper (Brown \& Newell 1972, Scott \& Major 1972). The same metal may also cause increased or decreased respiration depending on concentration or the animal species (Müller 1979). The systematic decrease in oxygen consumption found in periwinkles in Langesundfjord suggests contaminant depression of oxygen uptake, either directly or through lower activity. The mesocosm results suggest that copper suppresses respiration since rates for $L, M$ and $H$ periwinkles were significantly below those for $\mathrm{C}$, as well as below the rates found in earlier experiments with Solbergstrand populations at $10^{\circ} \mathrm{C}$; also, diesel oil alone at similar concentrations causes an increase or no-change in periwinkle respiration (Bakke 1986, unpubl.). Suppressed respiration would tend to counteract a negative effect of pollution on feeding and assimilation in the SFG equation, making SFG less sensitive as an index of pollution than its component processes.

The $O: N$ ratio was also unable to define pollution gradients in field and mesocosms. Of all periwinkle populations only the mesocosm $M$ group had an $\mathrm{O}: \mathrm{N}$ ratio below 30, which in mussels is indicative of excessive catabolism of proteins (Widdows 1985). The basis for evaluating this value in periwinkles is weak. In previous experiments at Solbergstrand, $\mathrm{O}: \mathrm{N}$ ratios below 30 were generally found only in April $\left(7^{\circ} \mathrm{C}\right)$ at the beginning of the feeding season (Bakke unpubl.). $\mathrm{O}: \mathrm{N}$ ratios below this level may therefore also indicate enhanced catabolism of protein reserves in Littorina littorea.

The present investigation underlines several difficulties in applying energy physiology of Littorina littorea for monitoring pollution effects. Before such application can be recommended, considerable research has to be done on external and internal factors regulating the basic energy conversion processes in the species, as well as on methods of estimating natural food consumption rates and absorption efficiency. Considering the key role of the species in the rocky shore community, its wide geographical distribution, and the fact that its feeding mode is different from several currently used sentinel organisms, the efforts in establishing the biological basis for the use of L. littorea physiology in pollution monitoring should be pursued.

Acknowledgements. The author is indebted to the technical staff at the Marine Research Station, Solbergstrand for practical assistance during the GEEP Workshop and to the analytical laboratory at NIVA for performing the ammonia analyses. This study was made possible through funding from the Norwegian Council for Scientific and Industrial Research (NTNF).

\section{LITERATURE CITED}

Abdullah, M. I., Steffenak, I. (1988). The GEEP Workshop: trace metal analyses. Mar. Ecol. Prog. Ser. 46: 27-30

American Public Health Association (APHA) (1985). Standard methods for the examination of water and wastewater, 16th edn. APHA, Washington

Bakke, T. (1986). Experimental long term oil pollution in a boreal rocky shore environment. In: Proceedings of the Ninth Arctic Marine Oil Spill Technical Seminar, Beauregard Press, Canada, p. 167-178

Bakke, T., Follum, O. A., Moe, K. A., Sorensen, K. (1988). The GEEP Workshop: mesocosm exposures. Mar. Ecol. Prog. Ser. 46: 13-18

Brown, B. E., Newell, R. C. (1972). The effect of copper and zinc on the metabolism of the mussel Mytilus edulis. Mar. Biol. 16: 108-118

Conover, R. J. (1966). Assimilation of organic matter by zooplankton. Limnol. Oceanogr. 11: 338-345 
Crisp, D. J. (1971). Energy flow measurements. In: Holme, N. A., McIntyre, A. D. (eds.) Methods for the study of marine benthos. IBP Handbook No 16, Blackwell, Oxford, p. $197-279$

Elliott, J. M., Davison, W. (1975). Energy equivalents of oxygen consumption in animal energetics. Oecologia (Berl.) 19: $195-201$

Follum, O. A., Moe, K. A. (1988). The GEEP Workshop: field sampling. Mar. Ecol. Prog. Ser. 46: 7-12

Grahame, J. (1973). Assimilation efficiency of Littorina littorea (L.) (Gastropoda: Prosobranchiata). J. anim. Ecol. 42: $383-389$

Hargrave, B. T., Newcombe, C. P. (1973). Crawling and respiration as indices of sublethal effects of oil and a dispersant on an intertidal snail Littorina littorea. J. Fish. Res. Bd Can. 30: $1789-1792$

Livingstone, D. R. (1988). Responses of microsomal NADPHcytochrome $c$ reductase activity and cytochrome P-450 in digestive glands of Mytilus edulis and Littorina littorea to environmental and experimental exposure to pollutants. Mar. Ecol. Prog. Ser. 46: 37-43

Lubchenko, J. (1978). Plant species diversity in a marine intertidal community: importance of herbivore food preference and algal competitive abilities. Am. Nat. 112: 23-39

Moore, M. N. (1988). Cytochemical responses of the lysosomal system and NADPH-ferrihemoprotein reductase in molluscan digestive cells to environmental and experimental exposure to xenobiotics. Mar. Ecol. Prog. Ser. 46: 81-89

Müller, D. von (1979). Sublethale und lethale Schädigungen von Vertretern der Lebensgemeinschaft der Außenelbe- watten durch die Schwermetalle Kupfer, Cadmiurn und Blei. Arch. Hydrobiol. 43 (Suppl.): 289-346

Newell, R. C., Pye, V. I. (1971). Quantitative aspects of the relationship between metabolism and temperature in the winkle Littorina littorea (L.). Comp. Biochem. Physiol. 38B: $635-650$

Paine, R. T., Vadas, R. L. (1969). Calorific values of benthic marine algae and their postulated relation to invertebrate food preference. Mar. Biol. 4: 79-86

Scott, D., Major, C. W. (1972). The effect of copper (II) on survival respiration, and heart rate in the common blue mussel, Mytilus edulis. Biol. Bull. mar. biol. Lab., Woods Hole 143: 679-688

Thurberg, F. P., Calabrese, A., Dawson, M. A. (1974). Effects of silver on oxygen consumption of bivalves at various salinities. In: Vernberg, F. J., Vernberg, W. B. (eds.) Pollution and physiology of marine organisms. Academic Press, New York, p. 67-78

Warren, C. E., Davies, G. E. (1967). Laboratory studies on the feeding, bio-energetics and growth of fish. In: Gerking, S.D. (ed.) The biological basis of freshwater fish production. Blackwell, London, p. 175-214

Widdows, J. (1985). Physiological responses to pollution. Mar. Pollut. Bull. 16: 129-134

Widdows, J., Bayne, B. L., Donkin, P., Livingstone, D. R., Lowe, D. M., Moore, M. N., Salkeld, P. N. (1981). Measurement of the responses of mussels to environmental stress and pollution in Sullom Voe: a base-line study. Proc. R. Soc. Edinb. 80B: 323-338 